\title{
Effect of Cohesive Contact of Backfill with Arch and Spandrel Walls of a Historical Masonry Arch Bridge on Seismic Response
}

\author{
Emin Hokelekli^, Betul Nihan Yilmaz ${ }^{1}$ \\ ${ }^{1}$ Faculty of Engineering, Architecture and Design, \\ Bartın University, 74110, Batın, Turkey \\ *Corresponding author, e-mail: ehokelekli@bartin.edu.tr
}

Received: 11 April 2019, Accepted: 09 August 2019, Published online: 13 September 2019

\begin{abstract}
Historical masonry bridges generally consist of arches, spandrels walls, backfills, piers and foundations. Under the effects such as earthquake, flood and wind, the most vulnerable structural elements of bridges against out-of-plane seismic motions are spandrel walls. Increasing length and height of spandrel walls increases the vulnerability of the bridge under loads in vertical and transverse directions. The aim of this research is to examine the in-plane and out-of-plane non-linear structural responses of the spandrel walls of a historical masonry bridge. For this purpose, a historical masonry arch bridge with built in 1787 in Bartın-Turkey was chosen as the subject structure. The 3D finite element model and nonlinear seismic analyses of the bridge were performed with ABAQUS. Initially, the backfill-spandrels and backfill-arch interfaces of the bridge were modeled with and without cohesive contact. The nonlinear material responses of the spandrel walls and the arch units were defined using Concrete Damage Plasticity material model and those of the backfill unit were defined with Mohr-Coulomb material model. The east-west component of 17 August 1999 Kocaeli Earthquake's acceleration records was used in the analyses. The east-west acceleration component was applied on the bridge in-plane and out-of-plane directions during the time-history non-linear seismic analysis of the bridge. The results obtained from the analyses with and without the consideration of cohesive contact were compared to evaluate the seismic responses of the spandrel walls. As a result, cohesive interface behavior was found to significantly affect the spandrel wall response under in- plane and out-of-plane seismic forces.
\end{abstract}

\section{Keywords}

historical stone bridge, seismic analysis, cohesive interface behavior, in-plane and out-of-plane, concrete damage plasticity model

\section{Introduction}

As cultural heritages, historical bridges maintain their function as a part of transportation systems as from the date they are built. Throughout their lifetime, such structures are exposed to several natural disasters, hence the necessity to take protective measures. Structural and non-structural elements of masonry arch bridges comprise of foundations, arches, spandrel walls and backfill, and these structures have been built using masonry wall technique [1].

The loads exerted on masonry bridges are their own weight, heavy traffic load in the vertical direction, and seismic, flood and wind loads in the out-of-plane direction. Among these loads, earthquakes and floods are considered as the most effective ones as they induce the highest damage [2]. Due to high compressive strength of stone materials used in historical bridges, the stresses arising

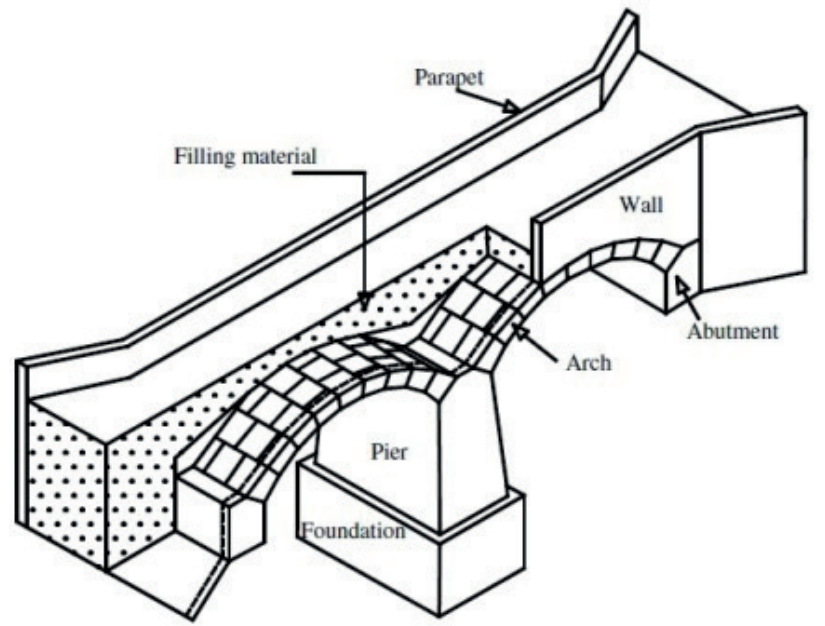

Fig. 1 The main components of a masonry arch bridge [1] 
from vertical loads are easily overcome. Also, the use of arch form in long distances is another effective factor in overcoming compressive stresses. Significantly higher weight of masonry bridges in comparison to other types results in higher seismic loads during earthquakes. Low tensile strength of mortar between stone units that constitute the masonry wall in bridges also results in higher damages in the case of out-of-plane seismic loads. Particularly, the damages arising in spandrel-backfill and spandrel-arch interfaces induce further damages and collapse of bridge walls [3]. Collapse of spandrel walls and the loss of backfill are frequently encountered after earthquakes. Such damages are commonly attributed to spandrel-backfill and spandrel-arch interactions [1]. Determination of structural behaviors of historical masonry bridges is essential for preserving their structural integrity and minimizing the possible damages of seismic events. Several experimental and analytical studies are available in the literature on finite element modeling of historical masonry bridges and determination of their seismic behavior. The studies introduced so far on masonry arch bridges are summarized below.

Brencich and Sabia [4] conducted a series of material tests for use in FEM modeling of the Tanaro Bridge. They compared the results of the dynamic tests and FE analyses and accordingly verified the reliability of the methods they used to determine material characteristics. Bayraktar et al. [5] examined the dynamic characteristics of two-span masonry arch bridge using experimental and analytical methods. They calibrated their finite element model by covering their analytically obtained findings to the experimental results. They reported that, the frequencies obtained from their FE model showed consistency with the experimentally obtained frequencies. Sevim et al. [6] investigated the effect of finite element model calibration on the seismic behavior of masonry arch bridges. They suggested that, finite element model calibration is significantly effective on the structural behavior. Özmen and Sayın [7] performed linear and non-linear seismic analyses on historical Uzunok Bridge. Their evaluations as to the subject seismic behavior were based on a comparative analysis of their results. Bayraktar et al. [8] experimentally determined the dynamic characteristics of eight different masonry stone bridges and proposed an equation for determination of the first frequency value of masonry stone bridges. Ercan and Nuhoglu [9] investigated the seismic behavior of a historical stone bridge. Zampieri et al. [10] proposed a simplified method for seismic reinforcement of structural elements of multi-span arch bridges. Bayraktar et al. [5] investigated the effect of arch thickness on the structural behavior of a bridge under static and dynamic loads. The increase in the arch thickness was found to reduce the tensile stresses and strains, and increase the compressive stresses and strains. Güllü and Jaf [11] performed the non-linear analyses of the historical Malabadi Bridge on the basis of soil-structure interactions. Reportedly, the soil structure interaction was effective on the structural behavior in question. Olmos et al. [12] performed an experimental study to determine the dynamic characteristics of historical masonry bridges in Mexico using Operational Modal Analysis method. They stated that, a numerical model can be developed using the experimental data Martinelli et al. [13] evaluated the load bearing capacity of a historical arch bridge. Severini et al. [14] investigated the effect of masonry arches with irregular geometry on the dynamic behavior of overall structure. Aydın and Özkaya [15] studied the behavior of single span arch bridges under static vertical loads applied on different sections of the structure. Zhang et al. [16] studied the behavior of masonry arch bridges under vertical loads taking into account the interaction between structural and non-structural elements, and proposed a finite element modeling strategy. Naderi and Zekavati [17] examined the seismic behavior of a masonry stone bridge using discrete element method.

The above mentioned studies addressed the linear and non-linear behaviors of masonry stone arch bridges under static and dynamic effects. Despite their superior strength particularly against vertical loads, arch bridges are vulnerable to in-plane and out-of-plane effects. Particularly, out-of-plane seismic forces may induce the damage or collapse of spandrel walls. Collapse of spandrel walls leads to the loss of backfill (Fig. 2). Such structural damages are mainly ascribed to the weakness of spandrel-backfill and spandrel-arch interaction [1].

Despite their superior strength and safety against vertical loads, masonry bridges are highly susceptible to lateral loads [3]. Fanning et al. [18] investigated out-of-plane structural behavior of masonry bridges under service loads. They reported that arch thickness and spandrel wall height are significantly effective on the overall strength of the structure. It is reported by some of the researchers that, out-of-plane forces are effective on determination of seismic behaviors of arch bridges with long archspan and high spandrel walls [1, 10, 19] Pulatsu et al. [20] examined the damage situations of masonry arch bridges 


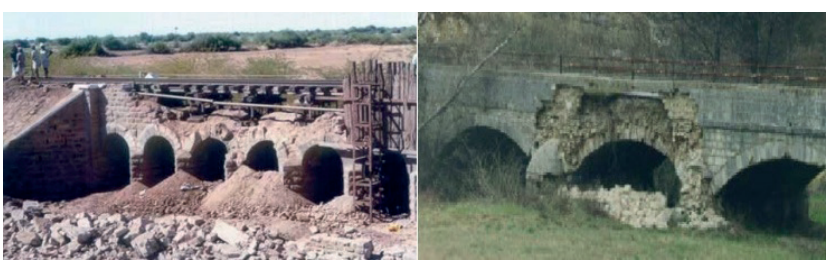

Fig. 2 A railroad bridge damaged in India 2001 Bhurj earthquake [1]

under diverse loads by comparing in-and-out-of-plane behaviors. It was further emphasized that the damages likely to occur on spandrel walls induced by out-of-plane loads affect the load bearing capacity of the structure. Bayraktar et al. [20] investigated the non-linear seismic out-of-plane behavior of the spandrel walls of the historical Bridge Malabadi. Numerous studies are available on determination of seismic behavior of masonry bridges using discrete element method, however, no comprehensive work has been conducted on the out-of-plane behavior of spandrel under vertical seismic load taking into account the spandrel-backfill and spandrel-arch interactions.

The aim of this work is to investigate the effect of the interaction between the structural and non-structural elements of masonry arch bridges on the seismic behavior in addition to the damage situation. For this purpose, a historical arc bridge in Bartın Province, Turkey was chosen as the subject of the present work. Concrete Damage Plasticity (CDP) material model was used for definition of non-linear behavior of the masonry units constituting the bridge's load bearing system. Spandrel walls-backfill and arches-backfill interactions were considered in the finite element model. Non-linear earthquake analyses were conducted in time history under in-plane and out-of-plane seismic effects. The east-west component of 1999 Kocaeli earthquake $(M w=7.2)$ with the highest acceleration value was used in the non-linear seismic analyses. Maximum displacements, and maximum and minimum principal stresses were used during the analyses to determine the stress concentration regions. Evaluations were made as to the seismic behaviors of the bridge under in-plane and outof-plane seismic loads.

\section{Numerical modeling of masonry structures}

Masonry elements of historical arch bridges consist of stones/bricks and mortars. Numerical modeling of masonry structures is highly complex due to the interaction between masonry units and the mortar. In accordance with the size of the structural system, detailed micro, simplified micro and macro modeling techniques have been used in the modeling of masonry units (Fig. 3) [21].

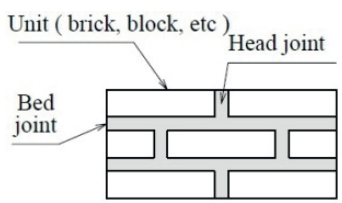

a) Masonry sample

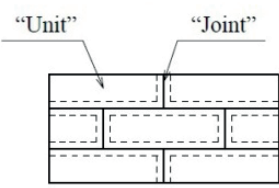

c) Simplified micro-modelling

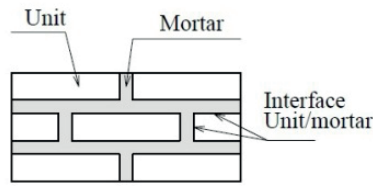

b) Detailed micro-modelling

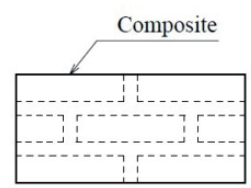

d) Macro-modelling
Fig. 3 Material modeling techniques [21]

In detailed micro modelling, masonry units (stone/brick) and mortar are separately modelled. Therefore, different material properties are defined for the elements constituting masonry units. In the simplified micro modelling technique, masonry units are built at a width half of the mortar layer and the mortar layer is neglected. In the finite element model, arches, side walls and backfill are separately modelled. In the macro modelling technique, the masonry unit and mortar are modelled as a whole. Material properties of masonry walls are determined by empirical formula from the literature by considering the material properties of masonry stone units and mortar constituents. Due to their complex geometric features, modelling of mosques, churches, minarets, towers and bridges involves the use of macro modelling technique [7, 22-23, 29-32].

\section{Masonry units and interface interaction}

\subsection{Material model for masonry units}

Dracker-Prager, Mohr-Coulomb and Concrete Damage Plasticity (CDP) modelling techniques have been commonly used to define the non-linear material behavior of masonry units. In this research, the non-linear behavior of masonry units was modeled using Concrete Damage Plasticity (CDP) model proposed by Lubliner et al. [33]. This CDP model was adapted for masonry structures by Lee and Fenves [34]. The related literature involves numerous works in which CDP was used for modelling of non-linear behavior of masonry units [24, 25, 30, 35-37].

CDP model characterizes uniaxial tensile and compressive behaviors of concrete by taking into account the different damage parameters of the structures, as shown in Fig. 5. In the case of tensile behavior, the material exhibits linear elastic behavior until the peak stress $\left(\sigma_{t 0}\right)$ is reached. When the peak stress is reached, micro crack formations occur on the material. After the peak stress is exceeded, the stress-strain behavior exhibited is characterized with 
softening of the material (Fig. 4a). Under uniaxial compressive loads, material behaves linearly until the peak stress $\left(\sigma_{c 0}\right)$. At the peak stress point, crushing of the material is observed. Beyond the peak stress, the material is characterized with softening (Fig. 4b).

In the CDP model, four fundamental material parameters should be defined to accurately simulate the non-linear behavior in addition to the definition of stress-strain relationship. These parameters, reported by Valente and Milani [39] are given in Table 1.

\subsection{Cohesive interface model}

The simplified macro modelling technique, in which the mortar thickness is assumed to be zero and the masonry unit dimensions are accordingly increased by mortar thickness, have been commonly used in the literature. In this approach, the interface between the masonry units is required to have a representative stiffness so as to prevent

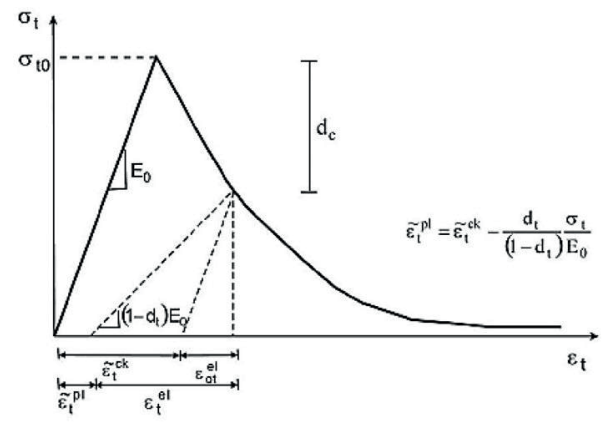

a) Unaxial tension

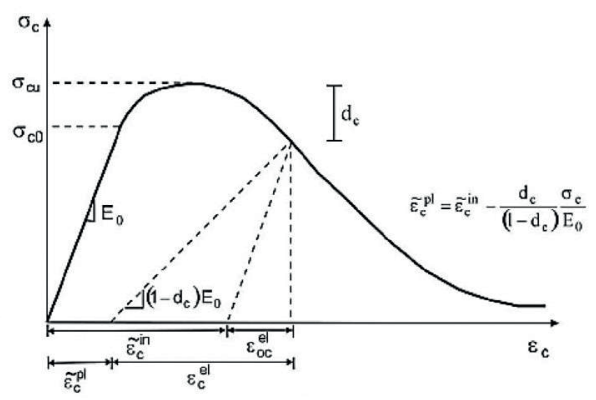

b) Unaxial compression

Fig. 4 Concrete damage plasticity stress-strain diagrams [38]

Table 1 Mechanical properties adopted for the analyses [39]

\begin{tabular}{ccc}
\hline Type & Parameter & Value \\
\hline Dilatation angle & $10^{\circ}$ \\
Eccentricity & 0.10 \\
Concrete & Ramage & mono-axial $\left(\sigma_{c 0}\right)$ compression strength \\
Plasticity & $\mathrm{K}$ & 1.16 \\
& Viscosity parameter & 0.666 \\
\end{tabular}

the continuous interface media from interfering with each other. This is a plane in which surface-tensile induced opening and shearing is likely to occur [40]. Some of the related studies involve the use of masonry unit interfaces as cohesive interface for modelling. In this approach, the elastic interface stiffness should be calculated in consideration of mortar and masonry unit (stone/brick) material properties as the mortar is not modeled [41-45]. In simplified macro modelling, the normal and shear stiffness of the interface are calculated using Eqs. (1-3). The behavior of masonry unit interfaces under normal and shear stresses is shown in Fig. 5.

$$
\begin{aligned}
& k_{n n}=\frac{E_{u} E_{m}}{t_{m}\left(E_{u}-E_{m}\right)}, \\
& k_{s s}=\frac{G_{u} G_{m}}{t_{m}\left(G_{u}-G_{m}\right)}, \\
& G=\frac{E}{t_{m}(1+v)},
\end{aligned}
$$

where $k_{n n}$ and $k_{s s}$ denote the interface normal and shear stiffness, $E_{u}$ and $E_{m}$ denote the modulus of elasticity of the masonry unit and the mortar, respectively, $G$ denotes the shear modulus of the masonry unit and the mortar, and $t_{m}$ denotes the thickness of the interface (mortar).

Spandrel walls-backfill, and arches-backfill interactions play a crucial role in accurate determination of masonry bridges' behaviors. In this research, side walls, arches and backfill units were connected using surface-to-surface contact. Normal, tangential and cohesive behaviors were used as the contact properties.

\subsection{Historical Stone Arc bridge}

The Arc Bridge, the first stone bridge of Bartın Province, was built in 1787. Every day, thousands of vehicles and pedestrians use the bridge which is over Kozcagız River. The total length of the two-span bridge is $44 \mathrm{~m}$, the span length is $12.5 \mathrm{~m}$, width is $8.5 \mathrm{~m}$, height is $7.8 \mathrm{~m}$ and the length over the river is $30 \mathrm{~m}$. The load-bearing system of the bridge consists of basalt stone and mortar. The detailed dimensions and drawings of the bridge are shown in Fig. 6.
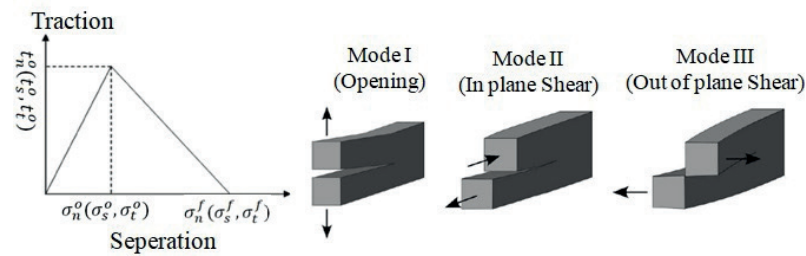

Fig. 5 Masonry unit cohesive interface behavior 

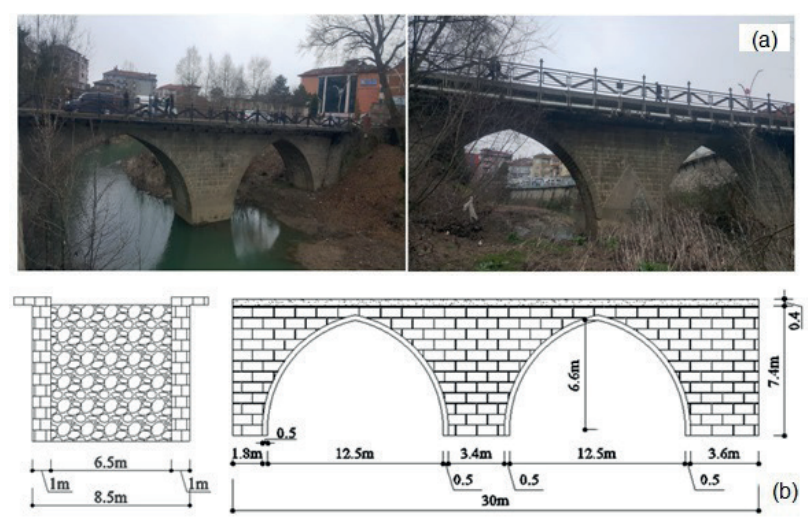

Fig. 6 Historical Arc Bridge, (a) View of Arc Bridge, (b) Cross and longitudinal section and dimensions of bridge

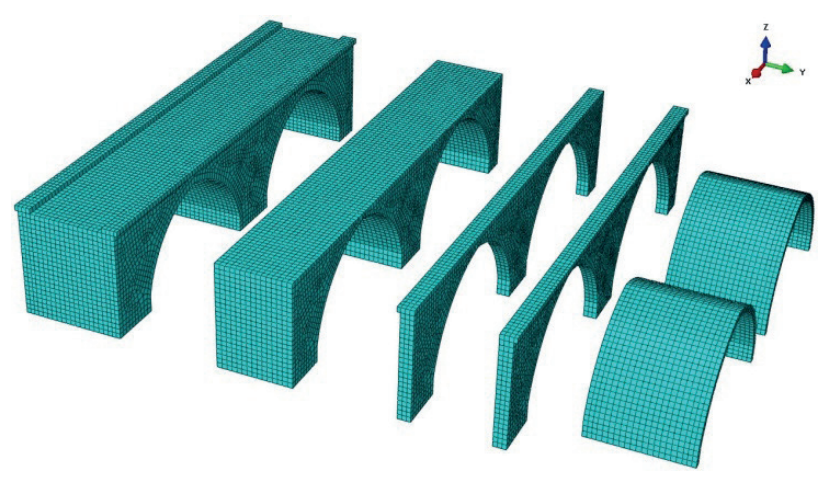

Fig. 7 Three dimensional finite element model of the bridge

The 3D finite element model of the bridge was built using macro modelling techniques with ABAQUS V10 software. The finite element models of the arches, side walls and backfill units were separately established. 25989 nodes and 30732 eight node (C3D8) linear hexahedral elements were used in the finite element model (Fig. 7).

In the structures, the most important parameter affecting the structure behavior is material properties. However, definition of the material properties of historical structures is quite challenging. Therefore, the material parameters reported in the literature on masonry stone bridges were considered in this study [6, 15, 46-48]. Concrete Damage Plasticity model was used to simulate the nonlinear material behavior of the masonry wall and arch units, and Mohr Coulomb material model was used for the backfill unit. The material properties of the bridge used in the analyses are given in Table 2 .

\section{Modal behavior of the with and without cohesive contact of bridge model}

Several parameters are known to be effective on the structural behavior of masonry bridges. These involve the total length, the number of spans, the maximum length, height and the type of the arch, and the material properties. Finite
Table 2 Mechanical properties of masonry and interface units

\begin{tabular}{|c|c|c|c|c|}
\hline $\begin{array}{l}\text { Material } \\
\text { properties }\end{array}$ & $\begin{array}{l}\text { Stone } \\
\text { arches }\end{array}$ & $\begin{array}{c}\text { Side } \\
\text { walls }\end{array}$ & Backfill & Interface \\
\hline $\begin{array}{l}\text { Modulus of } \\
\text { Elasticity (MPa) }\end{array}$ & $2800-3000$ & $2400-2500$ & 500 & \\
\hline Poisson's ratio & $0.2-0.25$ & 0.20 & 0.25 & \\
\hline Density $\left(\mathrm{kg} / \mathrm{m}^{3}\right)$ & 1600 & 1400 & 1800 & \\
\hline $\begin{array}{l}\text { Compressive } \\
\text { Strength (MPa) }\end{array}$ & 5.0 & 5.0 & 1.0 & \\
\hline $\begin{array}{l}\text { Tensile } \\
\text { Strength (MPa) }\end{array}$ & 0.5 & 0.5 & 0.05 & \\
\hline Friction angle & & & 20 & \\
\hline Dilation angle & & & 0 & \\
\hline $\begin{array}{l}\text { Cohesion yield } \\
\text { stress }(\mathrm{MPa})\end{array}$ & & & 0.05 & \\
\hline $\begin{array}{l}\text { Normal Stiffness } \\
(\mathrm{MPa} / \mathrm{mm})\end{array}$ & & & & 2.45 \\
\hline $\begin{array}{l}\text { Shear Stiffness } \\
(\mathrm{MPa} / \mathrm{mm})\end{array}$ & & & & 1.21 \\
\hline
\end{tabular}

element modeling plays a crucial role in accurate determination of the structural behavior. For masonry structures, verification of the initial finite element model with tests or empirical formula is required. Bayraktar et al. [8] statistically defined the relationship between the maximum arch span and the first natural frequencies of eight masonry bridges using their natural frequencies (Eq. 4).

$y=-3.935 \ln (x)+16.824$,

where $x$ and $y$ symbols represent maximum arch span (in $\mathrm{m}$ ) and the first frequency (in $\mathrm{Hz}$ ), respectively. The theoretically (Eq. 4) and experimentally obtained first frequency values are shown in Table 3.

As indicated in Table 3 the experimentally and theoretically obtained values are close to each other. The authors thus concluded that Eq. (4) can be used in verification of the analytical model of masonry bridges. Eq. (4) is therefore used for verification of the finite element model of the arch bridge in this research as well. The first natural frequency of the arch bridge was accordingly calculated as $6.882 \mathrm{~Hz}$. The first three modes obtained from the modal analysis of the bridge without contact and with cohesive contact are shown in Fig. 8. Due to the insignificant difference between the experimentally and theoretically obtained first frequency values, we also propose that the built finite element model represents the real structural behavior in high accuracy. The cohesive behavior defined between the masonry unit elements were found to affect the second and the fourth frequency values although to a lesser extent. As the number of the modes increased, the difference 
Table 3 Correlation between the dynamic characteristics of the bridges

\begin{tabular}{|c|c|c|c|c|c|c|}
\hline \multirow{2}{*}{ Bridge } & \multirow{2}{*}{ Location } & \multirow{2}{*}{ Arc material } & \multirow{2}{*}{ Arc number } & \multirow{2}{*}{ Main arc span (m) } & \multicolumn{2}{|c|}{ The first natural frequency $(\mathrm{Hz})$} \\
\hline & & & & & Experimental & Using Eq. 5 \\
\hline Aspendos & Antalya & Stone & Seven & 16.00 & 5.890 & 5.914 \\
\hline Pehlivanlı & Erzurum & Stone & Single & 15.17 & 5.279 & 6.123 \\
\hline Mikron & Rize & Stone & Single & 19.49 & 6.063 & 5.137 \\
\hline Osmanlı & Rize & Stone & Two & 25.2 & 4.640 & 4.126 \\
\hline Şenyuva & Rize & Stone & Single & 24.8 & 4.045 & 4.189 \\
\hline Şahruh & Kayseri & Stone & Eight & 15.00 & 4.730 & 6.168 \\
\hline Osmanbaba & Trabzon & Stone & Two & 10.00 & 8.853 & 7.763 \\
\hline Torul & Gümüşhane & Stone & Three & 12.00 & 6.970 & 7.046 \\
\hline
\end{tabular}

between the frequencies became more distinct. When the mode shapes for the two models are compared, the first and the second mode shape develops in the longitudinal direction and the third and the fourth mode shapes develop in the vertical direction. Among the first 100 modes, mass contribution ratio was found to be $91 \%$ in the out-of-plane direction. Mass contribution ratio and the mode motion indicate that, the $1^{\text {st }}$ and the $2^{\text {nd }}$ mode shapes are effective in the out-of-plane behavior of the spandrel walls.

East-west component with the maximum acceleration value of 17 August 1999 Kocaeli (Turkey) earthquake was used in the time history non-linear seismic analyses of the bridge. Acceleration component records were received from Düzce station. The earthquake acceleration component was applied on the both models in-plane $(x)$ and outof-plane $(y)$ directions with and without the consideration of cohesive contact. The maximum acceleration value of the acceleration record is $3.71 \mathrm{~m} / \mathrm{s}^{2}$. Only first 10 th second of the $25^{\text {th }}$ second acceleration record was used to reduce the analyzing period (Fig. 9). Points A, B, C, and D on the acceleration time graph were considered in the evaluation of the analysis results.

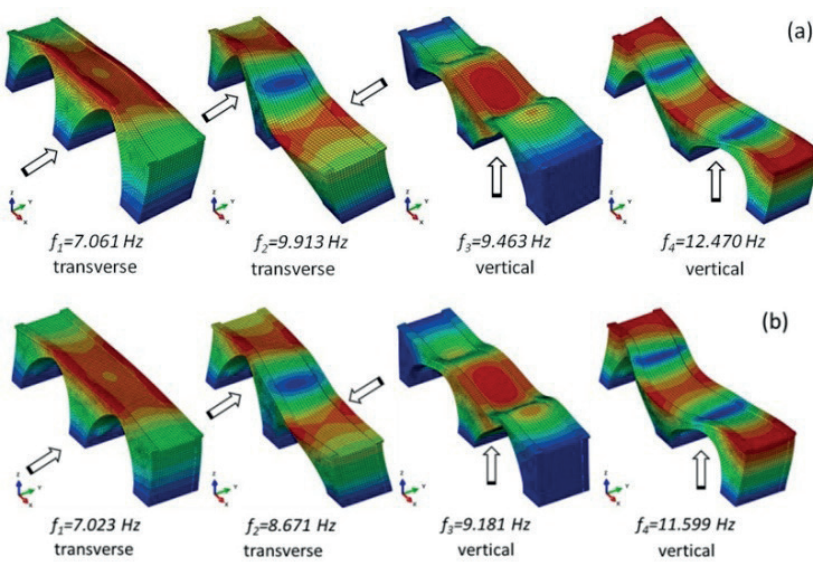

Fig. 8 Mode shapes; (a) without cohesive interface (b) with cohesive interface

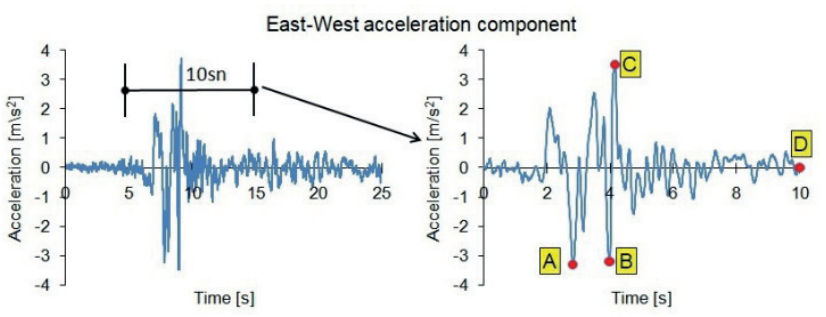

Fig. 9 East-West (E-W) acceleration component of 1999 Kocaeli earthquake, Turkey
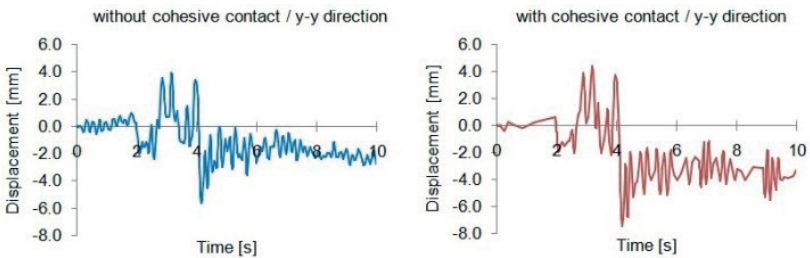

Fig. 10 Maximum displacement time graphics

In the non-linear analysis, damping ratios $\alpha_{R}$ and used in the dynamic analysis were determined as 2.454 and 0.0001 respectively. These values were calculated using Eq. (5) for $5 \%$ structural damping ratio.

$\alpha_{R}=\xi \frac{2 \omega_{i} \omega_{j}}{\omega_{i}+\omega_{j}}, \quad \beta_{R}=\xi \frac{2}{\omega_{i}+\omega_{j}}$,

where $\omega_{i}$ and $\omega_{j}$ denote the angular natural frequencies for $i^{\text {st }}$ and $j^{\text {th }}$ modes, and $\xi$ is the structural damping ratio.

\section{Out-of-plane seismic behavior of the bridge}

Maximum displacements on the bridge were found as 7 and $5 \mathrm{~mm}$ respectively for the models with and without cohesive contact (Fig. 10). Transition to nonlinear behavior was found to occur after the $4.14^{\text {th }}$ second (Point C) at which the acceleration value reached a peak. During the non-linear behavior, the maximum displacement of the model with cohesive contact was found to be higher than the non-contact condition, although to a small extent. 
The model with cohesive contact exhibited out-of-plane opening on the spandrel-backfill interface (Fig. 11). The size of the opening was determined as $0.81 \mathrm{~mm}, 3.05 \mathrm{~mm}$, $4.87 \mathrm{~mm}$ and $4.84 \mathrm{~mm}$ respectively for the different time steps (A, B, C and D) shown on the acceleration-time graph. The size of the opening on side walls-backfill interface was found to increase by the maximum acceleration value. The difference between the maximum acceleration value and the size of the opening at the end of the analysis was found to be significantly low, and the size of the opening was almost steady. Although the size of the opening in the side walls-backfill interface did not reach an extent that affects the bridge's structural behavior, the time dependent increase in the size of the opening is indicative of the importance of out-of-plane behavior for masonry bridges with higher side walls. The time-dependent graph of maximum (tensile) principal stresses obtained from the time-history non-linear analyses for cohesive contact and non-cohesive-contact situations are shown in Fig. 12. As indicated in the Fig. 12, the stresses that arise in the model with cohesive contact are higher. In the non-cohesive-contact model, maximum stresses concentrated at the arch region, whereas in the model with cohesive contact, the stresses concentrated at the spandrel wall regions. Emergence of tensile stresses on spandrel walls due to the out-of-plane seismic effects indicates that the model with cohesive contact provides a more accurate representation of the bridge's behavior.

The graph showing the time dependent change of maximum (tensile) plastic strains is given in Fig. 13. The tensile plastic strain values in spandrel walls were found to increase from 0.0036 to 0.0039 . Tensile plastic strains in the models with and without cohesive contact were found to concentrate around the regions close to the wall's bearing section between the arches. Tensile plastic strains have lower effect in the case of out-of-plane seismic effects in the model with cohesive contact.

The time dependent change of minimum (compressive) principal stresses and the concentrated stress regions are shown in Fig. 14. Minimum principal stresses in the models with and without cohesive contact were found to not exceed the value of $5 \mathrm{MPa}$ which is the limit compressive stress value for masonry walls. However, the stresses in the cohesive-contact-model were higher and closer to the limit value.

The time dependent change of plastic strains arising from compressive stresses and the stress concentration regions on the bridge are shown in Fig. 15. Compressive

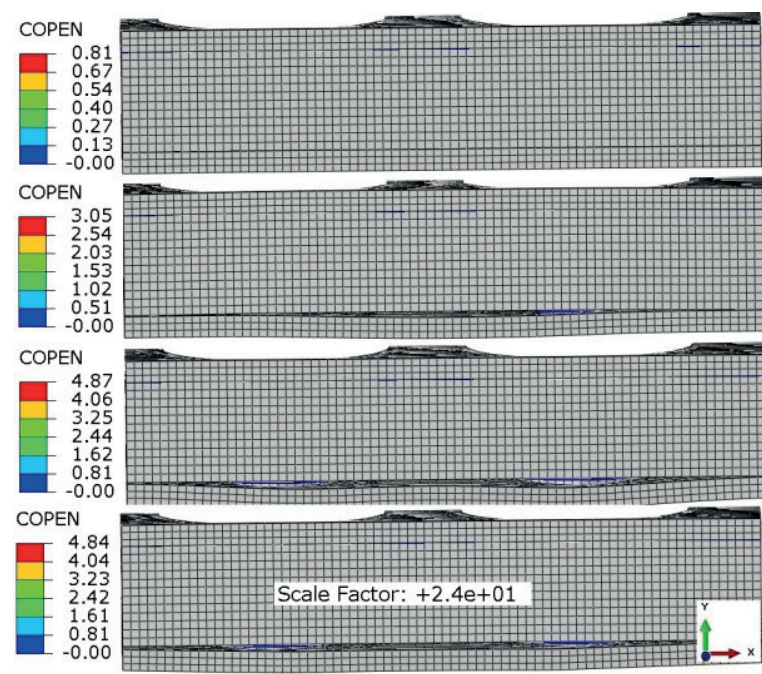

Fig. 11 Opening of spandrel walls with cohesive interface during the earthquake
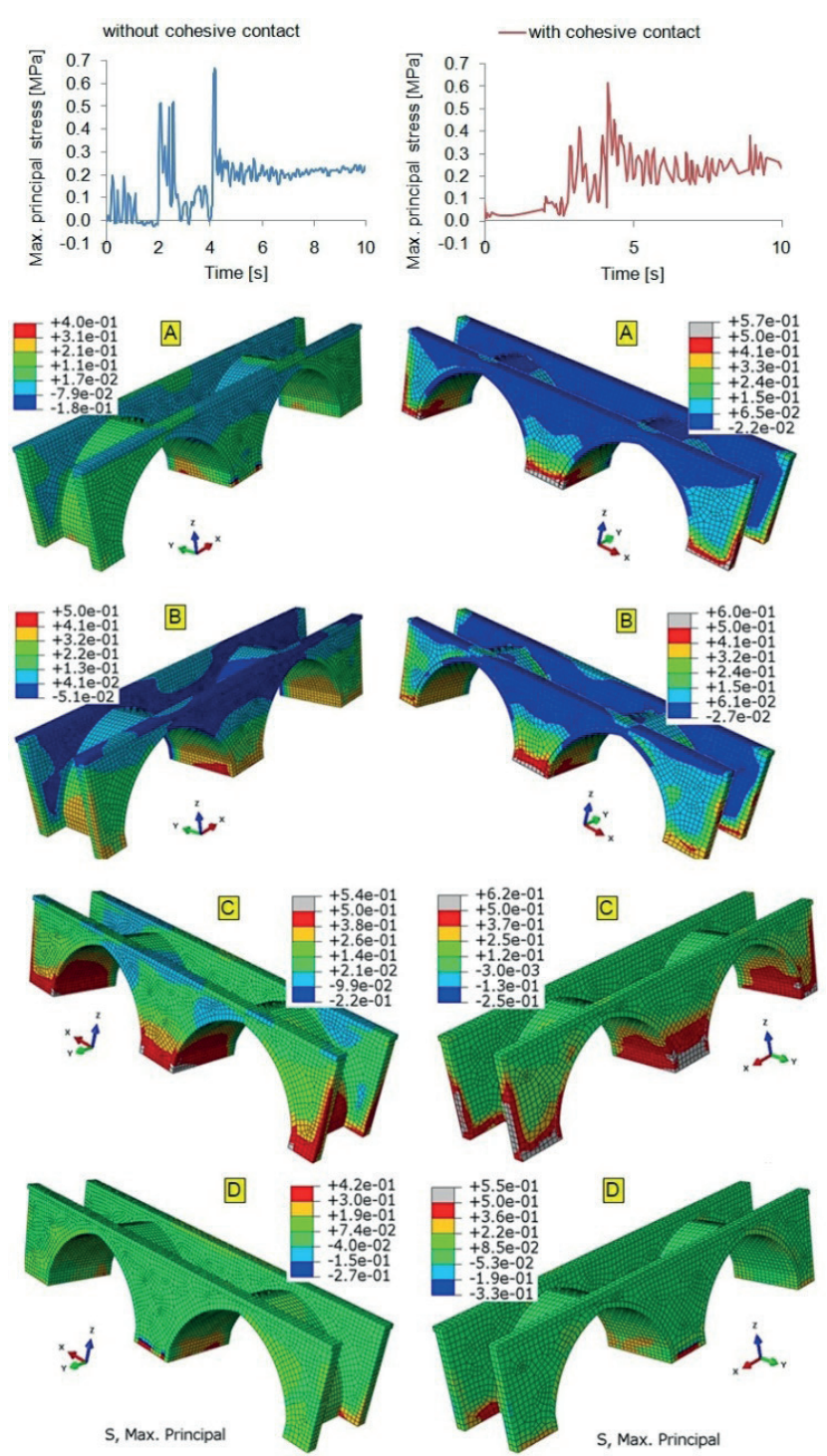

Fig. 12 Maximum principal (tension) stress contour maps of the bridge 

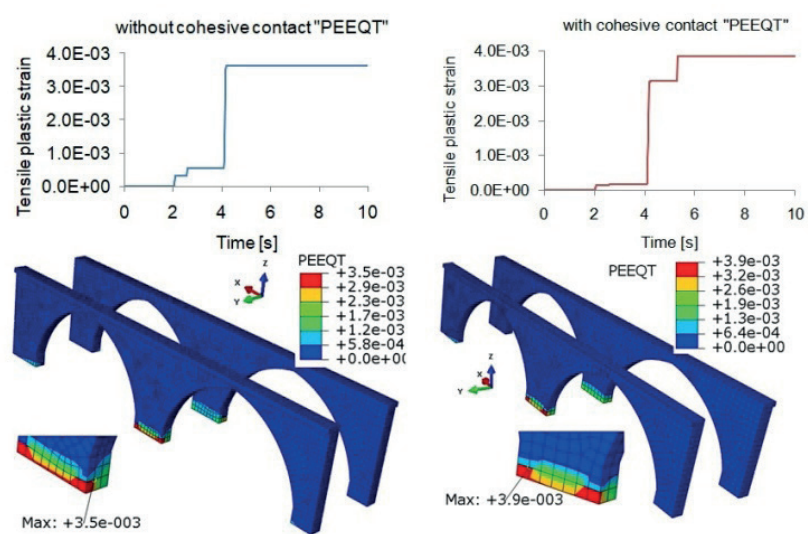

Fig. 13 Maximum principal (tension) strain contour maps of the bridge
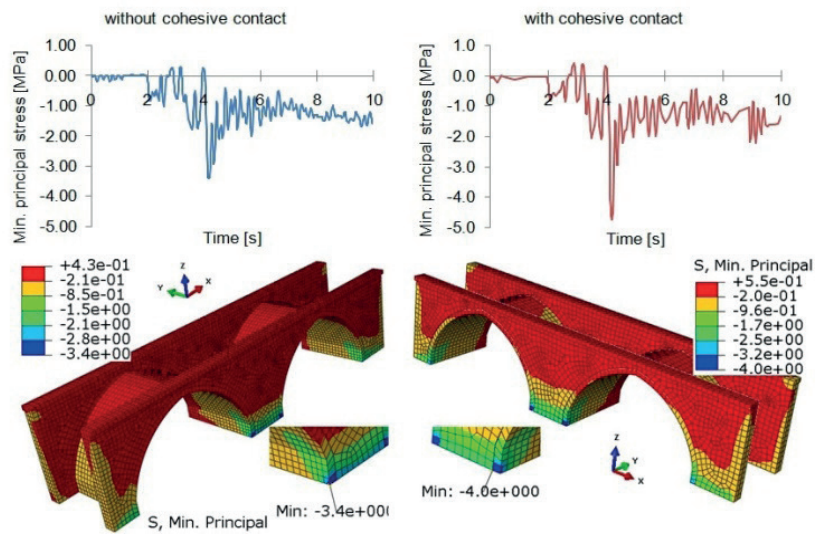

Fig. 14 Minimum principal (compression) stress contour maps of the bridge

plastic strains were found to concentrate on the same bridge elements, however they were found to be three fold higher as compared to the plastic strains in the case of contact situation.

\section{In-plane seismic behavior of the bridge}

Several studies are available on determination of the in-plane behavior of bridge spandrels walls. In these works, arches and spandrels walls were generally modelled in two and three dimensions and the spandrel walls-backfill and backfill-arches interactions were neglected. In the present work, a more comprehensive model of the bridge was built to simulate the in-plane behavior of the side walls by considering the cohesive and non-cohesive contact situations. The time dependent change of maximum displacements and the deformed version of the structure for the cohesive and non-cohesive contact conditions obtained from the time-history non-linear analyses are shown in Fig. 16. In the in-plane direction ( $\mathrm{x}-\mathrm{x})$ the maximum displacement was found as 8.5 and $17.7 \mathrm{~mm}$ respectively for non-cohesive contact and cohesive contact conditions.
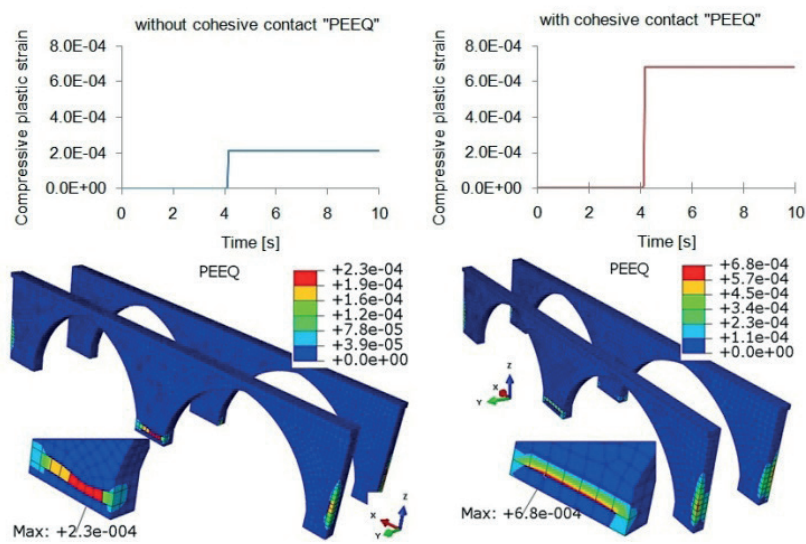

Fig. 15 Minimum principal (compression) strain contour maps of the bridge
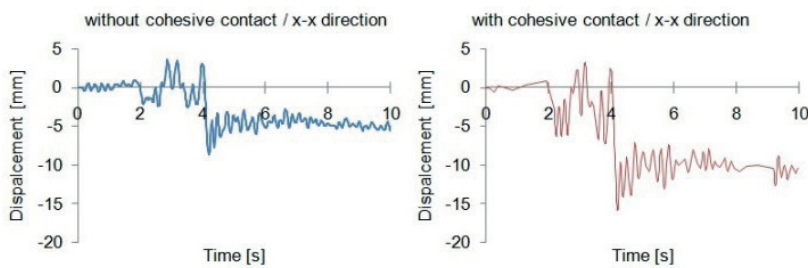

Fig. 16 Maximum displacement time graphics

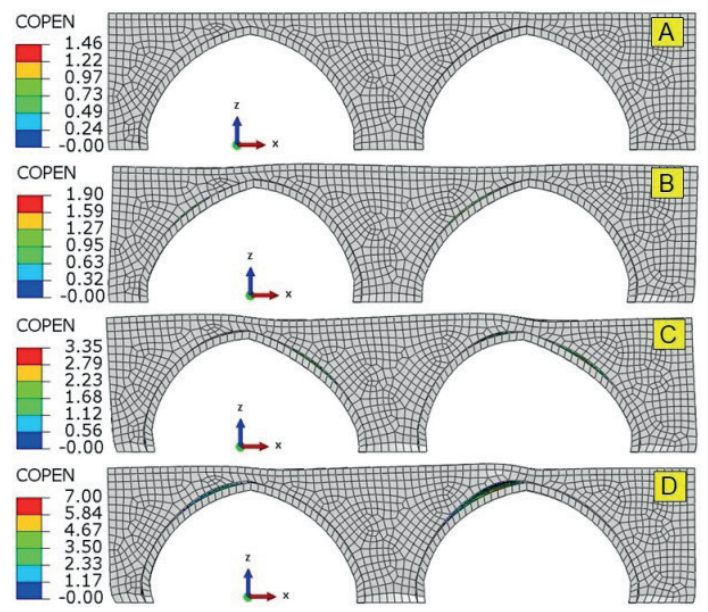

Fig. 17 Opening of spandrel walls with cohesive interface during the earthquake

An opening occurred in the spandrel-arch interface in cohesive contact situation (Fig. 17). The size of the opening was determined as $1.46 \mathrm{~mm}, 1.90 \mathrm{~mm}, 3.35 \mathrm{~mm}$ and $7.00 \mathrm{~mm}$ respectively for $\mathrm{A}, \mathrm{B}, \mathrm{C}$ and $\mathrm{D}$ points which are shown in Fig. 1. The size of the opening in the spandrel-arch interface increased throughout the analysis. This time-dependent increase is indicative of the importance of the in-plane behavior.

The time dependent change of maximum (tensile) principal stresses and the concentration regions are shown in Fig. 18. The maximum tensile principal stresses increased from 0.53 to $0.97 \mathrm{MPa}$. Such increase in tensile stresses 

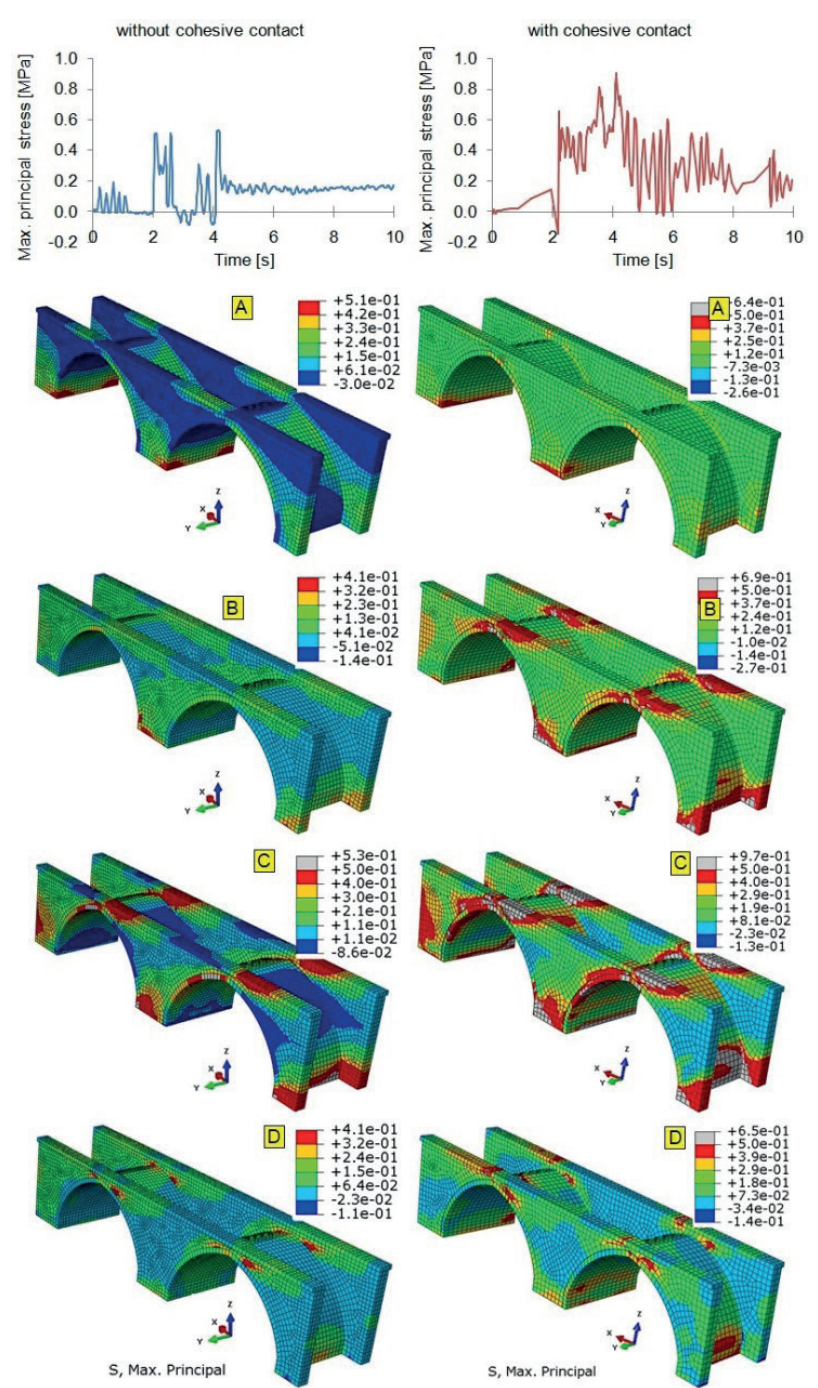

Fig. 18 Maximum principal (tension) stress contour maps of the bridge

is also indicative of the importance of the cohesive interface behavior. In the case of the model with cohesive contact, tensile stresses were found to exceed the masonry wall stress value by nearly two fold. The elements exceeding the wall limit stress values were found to concentrate around the spandrel wall and the arch. Tensile stresses emerging in the non-cohesive-contact model exceed the limit stress value only on a few elements. These few elements exceeding the limit stress value were found to concentrate on the arch region.

Tensile stress-induced tensile plastic strains were found to be three folds higher in the case of the model with cohesive contact. The time dependent change of plastic strains and concentration regions are shown in Fig. 19.

The time-dependent change of maximum (compressive) principal stresses obtained from the non-linear time history analysis, and the concentration regions are shown in Fig. 20. The minimum principal stresses did not exceed
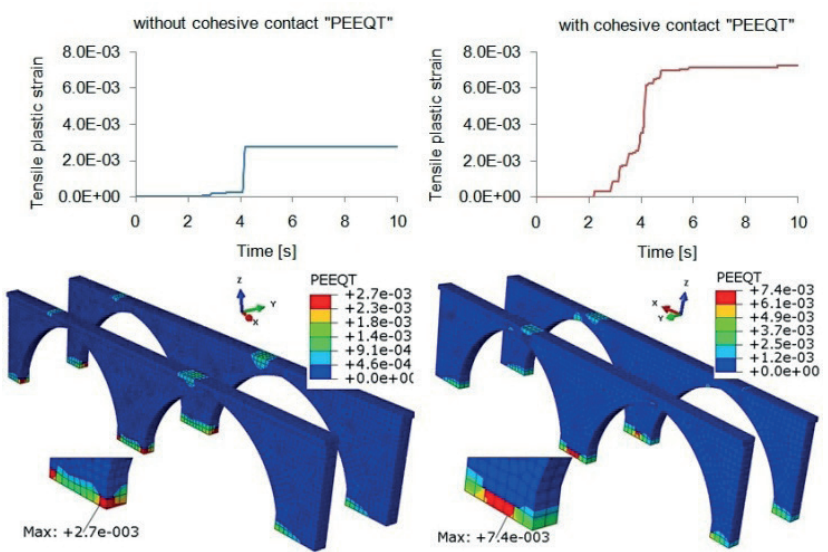

Fig. 19 Maximum principal (tension) strain contour maps of the bridge
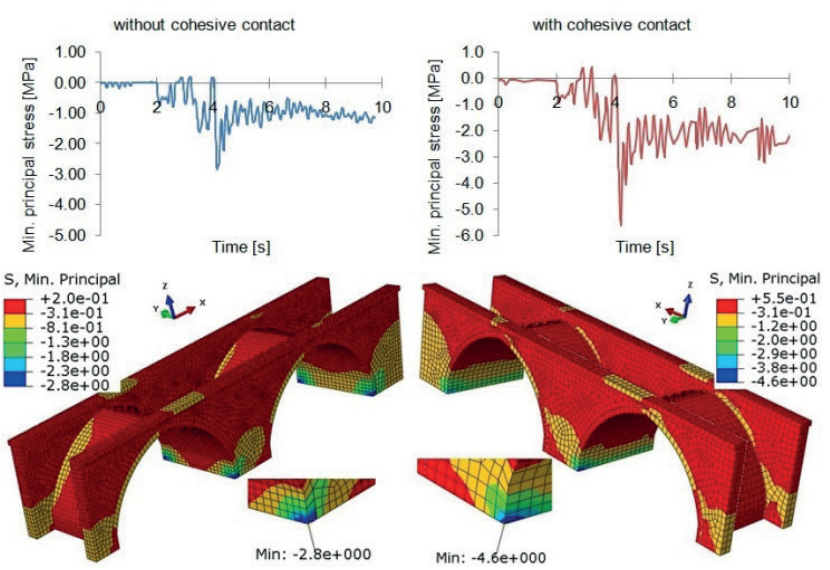

Fig. 20 Minimum principal (compression) stress contour maps of the bridge
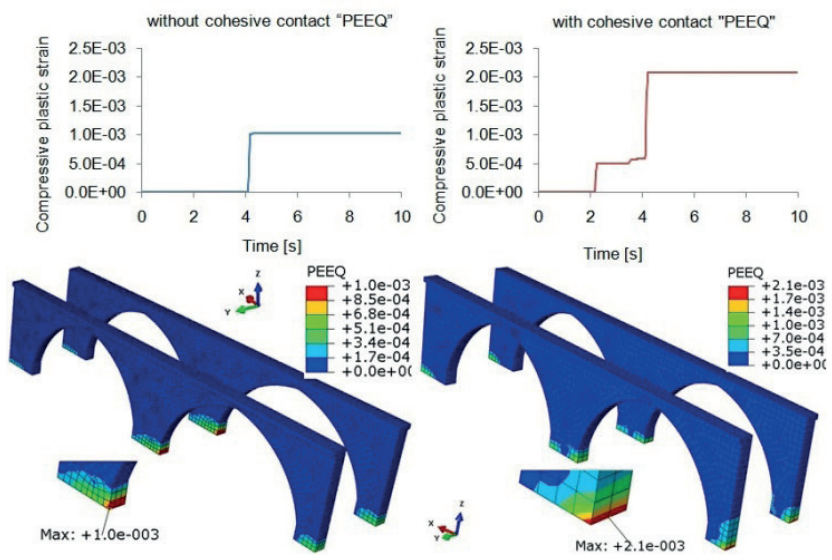

Fig. 21 Minimum principal (compression) strain contour maps of the bridge

$5 \mathrm{MPa}$ (the limit compressive stress value for masonry walls) in the model without cohesive contact, whereas they exceeded this value in the cohesive-contact model. The limited number of elements that exceeded the limit compressive stress value indicates that, this situation is not effective on the structural behavior of the bridge. 
The compressive plastic strains in the model with cohesive contact were found to be two folds higher. Also, plasticizing started at the $2.15^{\text {th }}$ second in the cohesive-contact-model, whereas it started at the $4.14^{\text {th }}$ second in the non-contact model (Fig. 21).

\section{Conclusions and recommendations}

The aim of this research was to examine the in plane and out-of-plane seismic behavior of a historical masonry bridge for cohesive and non-cohesive-contact conditions. Concrete Damage Plasticity material model was used to simulate the non-linear material behavior of masonry wall and arch units, and Mohr Coulomb material model was used for the backfill unit. Non-linear analyses were carried out in the time history to define the shear and opening conditions at the spandrels-backfill and arch-backfill interfaces of the bridge. The findings obtained from the analyses results and the corresponding evaluations are presented below.

When the cohesive interface behavior under in and outof-plane seismic forces is considered, the most vulnerable and susceptible elements of the bridge are spandrel walls. It is accordingly concluded that, the interaction between the masonry units is of great importance when establishing an accurate model for masonry arch bridges.

The normal and shear stiffness values for spandrels-backfill, spandrels-arch and backfill-arch interfaces are effective on the out-of-plane and in-plane behavior of the spandrel walls.

The interaction between masonry units was found to affect the frequencies of masonry stone bridges at the $2^{\text {nd }}$ and the $4^{\text {th }}$ frequencies, although to a small extent. In the both models, the 1 st and the $2^{\text {nd }}$ mode shapes occurred in the transverse direction, whereas the $3^{\text {rd }}$ and the $4^{\text {th }}$ mode shape occurred in the vertical direction.

In the model with cohesive contact, the opening in spandrels-backfill, spandrels-arch interfaces increased until reaching the maximum seismic record, and after this point, the increase continued although to a lesser extent.

In the cohesive contact model, under longitudinal seismic effect, the size of the opening in spandrels-backfill and spandrels-arch interface increased until the end of the analysis.

\section{References}

[1] Rota, M., Pecker, A., Bolognini, D., Pinho, R. "A Methodology for Seismic Vulnerability of Masonry Arch Bridge Walls", Journal of Earthquake Engineering, 9(2), pp. 331-353, 2005. https://doi.org/10.1142/s1363246905002432
The number of elements exceeding the limit tensile stress value for masonry walls was found to be higher for the model with cohesive contact under in-plane seismic effect.

Under out-of-plane seismic effect, tensile plastic strain and stress values were found to be higher for the model with cohesive interface. In this condition, tensile stresses were found to exceed the limit tensile stress value for masonry wall.

The compressive stresses arising from out-of-plane and in-plane seismic effects were found to exceed the limit value only at a few elements. This indicates that, cohesive interface was less effective on compressive stresses.

Out-of-plane seismic behavior of the bridge

Maximum displacement, maximum principal (tensile) stresses and minimum principal (compressive) stresses of the model with cohesive contact were found to be higher than the non-contact condition.

Maximum principal stresses in the model with cohesive contact were found to exceed the value of $0.5 \mathrm{MPa}$ which is the limit tensile stress value for masonry walls.

In the non-cohesive-contact model, maximum stresses concentrated at the arch region, whereas in the model with cohesive contact, the stresses concentrated at spandrel wall regions.

\section{In-plane seismic behavior of the bridge}

In the in-plane direction ( $\mathrm{x}-\mathrm{x})$ the maximum displacement was found as 8.5 and $17.7 \mathrm{~mm}$ respectively for non-cohesive contact and cohesive contact conditions.

In both models, the resulting maximum tensile stresses were found to exceed the limit value for masonry walls. In the contact situation, the limit stress value was exceeded at only one element, whereas it was exceeded in more elements in the non-contact situation. Such increase in tensile stresses and maximum displacements are also indicative of the importance of the cohesive interface behavior.

It was concluded that, the cohesive interface between spandrels-arch, spandrels-backfill and backfill-arch was significantly effective on the in-plane and out-of-plane behavior of the bridges spandrel walls. It is accordingly recommended that, the cohesive interface interaction between the masonry units should be considered when evaluating the structural behaviors of masonry bridges.

[2] Toker, S., Ünay, A. İ. "Mathematical Modeling and Finite Element Analysis of Masonry Arch Bridges", G. U. Journal of Science, 17(2), pp. 129-139, 2004. [online] Available at: http://gujs.gazi.edu. tr/article/view/1060000414 [Accessed: 08 April 2019] 
[3] Türker, T. "Structural evaluation of Aspendos (Belks) Masonry Bridge", Structural Engineering and Mechanics, 50(4), pp. 419439, 2014

https://doi.org/10.12989/sem.2014.50.4.419

[4] Brencich, A., Sabia, D. "Experimental identification of a multi-span masonry bridge: The Tanaro Bridge", Construction and Building Materials, 22(10), pp. 2087-2099, 2008.

https://doi.org/10.1016/j.conbuildmat.2007.07.031

[5] Bayraktar, A., Altunişik, A. C., Muvafik, M. "Damages of minarets during Erciş and Edremit earthquakes, 2011 in Turkey", Smart Structures and Systems, 14(3), pp. 479-499, 2014.

https://doi.org/10.12989/sss.2014.14.3.479

[6] Sevim, B., Bayraktar, A., Altunişik, A. C., Atamtürktür, S., Birinci, F. "Assessment of nonlinear seismic performance of a restored historical arch bridge using ambient vibrations", Nonlinear Dynamics, 63(4), pp. 755-770, 2011.

https://oi.org/10.1007/s11071-010-9835-y

[7] Özmen, A., Sayın, E. "Linear Dynamic Analysis of a Masonry Arch Bridge", In: CIEA 2018 International Conference on Innovative Engineering Applications, Sivas, Turkey, 2018, pp. 458-464.

[8] Bayraktar, A., Türker, T., Altunişik, A. C. "Experimental frequencies and damping ratios for historical masonry arch bridges", Construction and Building Materials, 75, pp. 234-241, 2015. https://doi.org/10.1016/j.conbuildmat.2014.10.044

[9] Ercan, E., Nuhoglu, A. "Identification of Historical Veziragasi Aqueduct Using the Operational Modal Analysis", The Scientific World Journal, 2014, Article ID: 518608, 2014. https://doi.org/10.1155/2014/518608

[10] Zampieri, P., Zanini, M. A., Modena, C. "Simplified seismic assessment of multi-span masonry arch bridges", Bulletin of Earthquake Engineering, 13(9), pp. 2629-2646, 2015. https://doi.org/10.1007/s10518-015-9733-2

[11] Güllü, H., Jaf, H. S. "Full 3D nonlinear time history analysis of dynamic soil-structure interaction for a historical masonry arch bridge", Environmental Earth Sciences, 75(21), Article ID: 1421,2016

https://doi.org/10.1007/s12665-016-6230-0

[12] Olmos, B. A., Jara, J. M., Martínez, G., López, J. I. "System identification of history Mexican masonry bridges", Procedia Engineering, 199, pp. 2220-2225, 2017 https://doi.org/10.1016/j.proeng.2017.09.186

[13] Martinelli, P., Galli, A., Barazzetti, L., Colombo, M., Felicetti, R., Previtali, M., Roncoroni, F., Scola, M., di Prisco, M. "Bearing capacity assessment of a 14th century arch bridge in Lecco (Italy)", International Journal of Architectural Heritage, 12(2), pp. 237-256. 2018. https://doi.org/10.1080/15583058.2017.1399482

[14] Severini, L., Cavalagli, N., DeJong, M., Gusella, V. "Dynamic response of masonry arch with geometrical irregularities subjected to a pulse-type ground motion", Nonlinear Dynamics, 91(1), pp. 609-624, 2018. https://doi.org/10.1007/s11071-017-3897-z

[15] Aydin, A. C., Özkaya, S. G. "The finite element analysis of collapse loads of single-spanned historic masonry arch bridges (Ordu, Sarpdere Bridge)", Engineering Failure Analysis, 84, pp. 131-138, 2018

https://doi.org/10.1016/j.engfailanal.2017.11.002
[16] Wang, W., Lu, C., Yuan, G., Zhang, Y. "Effects of pore water saturation on the mechanical properties of fly ash concrete", Construction and Building Materials, 130, pp. 54-63, 2017. https://doi.org/10.1016/j.conbuildmat.2016.11.031

[17] Naderi, M., Zekavati, M. "Assessment of seismic behavior stone bridge using a finite element method and discrete element method", Earthquake and Structures, 14(4), pp. 297-303, 2018. https://doi.org/10.12989/eas.2018.14.4.297

[18] Fanning, P. J., Boothby, T. E., Roberts, B. J. "Longitudinal and transverse effects in masonry arch assessment", Construction and Building Materials, 15(1), pp. 51-60, 2001. https://doi.org/10.1016/S0950-0618(00)00069-6

[19] Sarhosis, V., De Santis, S., de Felice, G. "A review of experimental investigations and assessment methods for masonry arch bridges", Structure and Infrastructure Engineering, 12(11), pp. 1439-1464, 2016. https://doi.org/10.1080/15732479.2015.1136655

[20] Pulatsu, B., Erdogmus, E., Bretas, E. M. "Parametric Study on Masonry Arches Using 2D Discrete-Element Modeling", Journal of Architectural Engineering, 24(2), 2018. https://doi.org/10.1061/(asce)ae.1943-5568.0000305

[21] Lourenço, P. S. B. B. "Computational Strategies for Masonry Structures", PhD Thesis, University of Porto, 1996.

[22] Nohutcu, H., Demir, A., Ercan, E., Hokelekli, E., Altintas, G. "Investigation of a historic masonry structure by numerical and operational modal analyses", The Structural Design of Tall and Special Buildings, 24(13), pp. 821-834, 2015. https://doi.org/10.1002/tal.1213

[23] Basaran, H., Demir, A., Ercan, E., Nohutcu, H., Hokelekli, E., Kozanoglu, C. "Investigation of seismic safety of a masonry minaret using its dynamic characteristics", Earthquake and Structures, 10(3), pp. 523-538, 2016 https://doi.org/10.12989/eas.2016.10.3.523

[24] Demir, A., Nohutcu, H., Ercan, E., Hokelekli, E., Altintas, G. "Effect of model calibration on seismic behaviour of a historical mosque", Structural Engineering and Mechanics, 60(5), pp. 749-760, 2016. https://doi.org/10.12989/sem.2016.60.5.749

[25] Nohutcu, H., Hokelekli, E., Ercan, E., Demir, A., Altintas, G. "Collapse mechanism estimation of a historical slender minaret", Structural Engineering and Mechanics, 64(5), pp. 653-660, 2017. https://doi.org/10.12989/sem.2017.64.5.653

[26] Ercan, E. "Assessing the impact of retrofitting on structural safety in historical buildings via ambient vibration tests", Construction and Building Materials, 164, pp. 337-349, 2018. https://doi.org/10.1016/j.conbuildmat.2017.12.154

[27] Sevim, B., Atamturktur, S., Altunişik, A. C., Bayraktar, A. "Ambient vibration testing and seismic behavior of historical arch bridges under near and far fault ground motions", Bulletin of Earthquake Engineering, 14(1), pp. 241-259, 2016. https://doi.org/10.1007/s10518-015-9810-6

[28] Conde, B., Ramos, L. F., Oliveira, D. V., Riveiro, B., Solla, M. "Structural assessment of masonry arch bridges by combination of non-destructive testing techniques and three-dimensional numerical modelling: Application to Vilanova bridge", Engineering Structures, 148, pp. 621-638, 2017. https://doi.org/10.1016/j.engstruct.2017.07.011 
[29] Karaton, M., Suha Aksoy, H., Sayın, E., Calayır, Y. "Nonlinear seismic performance of a 12 th century historical masonry bridge under different earthquake levels", Engineering Failure Analysis, 79, pp. 408-421, 2017.

https://doi.org/10.1016/j.engfailanal.2017.05.017

[30] Drygala, I., Dulinska, J., Bednarz, Ł., Jasienko, J. "Numerical evaluation of seismic-induced damages in masonry elements of historical arch viaduct", IOP Conference Series: Materials Science and Engineering, 364, Article ID: 012006, 2018. https://doi.org/10.1088/1757-899X/364/1/012006

[31] Di Sarno, L., da Porto, F., Guerrini, G., Calvi, P. M., Camata, G., Prota, A. "Seismic performance of bridges during the 2016 Central Italy earthquakes", Bulletin of Earthquake Engineering, 2018. https://doi.org/10.1007/s10518-018-0419-4

[32] Öztürk, Ş., Bayraktar, A., Hökelekli, E., Ashour, A. "Nonlinear Structural Performance of a Historical Brick Masonry Inverted Dome", International Journal of Architectural Heritage, 2019. https://doi.org/10.1080/15583058.2019.1592265

[33] Lubliner, J., Oliver, J., Oller, S., Oñate, E. "A plastic-damage model for concrete", International Journal of Solids and Structures, 25(3), pp. 299-326, 1989.

https://doi.org/10.1016/0020-7683(89)90050-4

[34] Lee, J., Fenves, G. L. "A plastic-damage concrete model for earthquake analysis of dams", Earthquake Engineering and Structural Dynamics, 27(9), pp. 937-956, 1998.

https://doi.org/10.1002/(SICI)1096-9845(199809)27:9<937::AIDEQE764>3.0.CO;2-5

[35] Barbieri, G., Biolzi, L., Bocciarelli, M., Fregonese, L., Frigeri, A. "Assessing the seismic vulnerability of a historical building", Engineering Structures, 57, pp. 523-535, 2013. https://doi.org/10.1016/j.engstruct.2013.09.045

[36] Costa, C. "Comparison of various modelling techniques applied in analysis of masonry arch bridges", In: 8th International Conference on Arch Bridges (ARCH'16), Wroclaw, Poland, 2016, pp. 835-842.

[37] Bayraktar, A., Hökelekli, E., Halifeoğlu, F. M., Mosallam, A., Karadeniz, H. "Vertical strong ground motion effects on seismic damage propagations of historical masonry rectangular minarets", Engineering Failure Analysis, 91, pp. 115-128, 2018. https://doi.org/10.1016/j.engfailanal.2018.04.029

[38] Dassault Systèmes Simulia Corp. "Abaqus V10", Providence, Rhode Island, USA, Available at: https://www.3ds.com/products-services/ simulia/products/abaqus/ [Accessed: 01 June 2018]
[39] Valente, M., Milani, G. "Non-linear dynamic and static analyses on eight historical masonry towers in the North-East of Italy", Engineering Structures, 114, pp. 241-270, 2016. https://doi.org/10.1016/j.engstruct.2016.02.004

[40] Milani, G., Lourenco, P. B. "3D non-linear behavior of masonry arch bridges", Computers and Structures, 110-111, pp. 133-150, 2012. https://doi.org/10.1016/j.compstruc.2012.07.008

[41] Lourenço, P. B., Rots, J. G. "Multisurface Interface Model for Analysis of Masonry Structures", Journal of Engineering Mechanics, 123(7), pp. 660-668, 1997. https://doi.org/10.1061/(ASCE)0733-9399(1997)123:7(660)

[42] Fanning, P. J., Boothby, T. E. "Three-dimensional modelling and full-scale testing of stone arch bridges", Computers and Structures, 79(29-30), pp. 2645-2662, 2001. https://doi.org/10.1016/S0045-7949(01)00109-2

[43] Macorini, L., Izzuddin, B. A. "A non-linear interface element for 3D mesoscale analysis of brick-masonry structures", International Journal for Numerical Methods in Engineering, 85(12), pp. 15841608, 2011. https://doi.org/10.1002/nme.3046

[44] Zhang, Y. "Advanced Nonlinear Analysis of Masonry Arch Bridges", MSc Thesis, Imperial College London, 2015. [online] Available at: https://spiral.imperial.ac.uk/handle/10044/1/29128 [Accessed: 08 April 2019]

[45] Kowalewski, Ł., Gajewski, M. "Determination of Failure Modes in Brick Walls Using Cohesive Elements Approach", Procedia Engineering, 111, pp. 454-461, 2015. https://doi.org/10.1016/j.proeng.2015.07.116

[46] Monaco, M., Gesuado, A., Frunzio, G. "3D F.E.M. analysis of a Roman arch bridge", In: Proceedings of the 3rd International Seminar, Guimarães, Portugal, 2001, pp. 591-598. [online] Available at: http://www.hms.civil.uminho.pt/events/historica2001/ [Accessed: 08 April 2019]

[47] Özmen, A., Sayın, E. "Seismic assessment of a historical masonry arch bridge", Journal of Structural Engineering \& Applied Mechanics, 1(2), pp. 95-104, 2018. https://doi.org/10.31462/jseam.2018.01095104

[48] Pelà, L., Aprile, A., Benedetti, A. "Comparison of seismic assessment procedures for masonry arch bridges", Construction and Building Materials, 38, pp. 381-394, 2013. https://doi.org/10.1016/j.conbuildmat.2012.08.046 